\title{
Comparative assessment of arbuscular mycoorhizal fungi (AMF) associated with Oroxylum indicum L. (Kurz.)- an ethno-medicinal plant of N. E. India.
}

Aatreyee Nath ${ }^{1}$, Liza Handique Bhattacharyya ${ }^{2 *}$, Pranaba Nanda Bhattacharyya ${ }^{3}$, Vipin Parkash ${ }^{2}$, Bijay Sharma ${ }^{1}$

${ }^{1}$ Department of Botany, Jagannath Barooah College, Jorhat 785001, Assam, India

2Silviculture and Forest Management Division, Rain Forest Research Institute, Jorhat 785001, Assam, India

${ }^{3}$ Mycology and Microbiology Department, Tocklai Tea Research Institute, Jorhat 785008, Assam, India.

Received: September 3, 2016; Revised: September 29, 2016; Accepted: October 11, 2016

\begin{abstract}
Oroxylum indicum L. (Kurz.) is an ethno-medicinally important plant of North East India. In the present investigation, a comparative study was conducted to assess the AM fungal associations of Oroxylum indicum (L.) Kurz. each at two sampling locations of Jorhat district, Assam and Mon district of Nagaland, N. E. India. Comparatively higher root colonization $(100 \pm 0)$ and maximum spore population $(1239 \pm 13.4)$ were observed in the rhizospheric samples of Mon district, Nagaland, the region which is geographically more distinct and diverse than the other study location. The rhizospheric samples of Jorhat district showed relatively lower spore count and AM colonization. The Shannon-Weinner and Simpson diversity indices were measured as maximum (2.935 and 0.941 respectively) in samples of Mon district, Nagaland. The results of the present investigation indicated the effect of geographical variations, environmental selection as well as alterations of edaphic factors in changing the AMF populations associated with Oroxylum indicum, an ethnomedicinally important plant of NE India.
\end{abstract}

Key words: AM fungi; edaphic factors; ethno-medicinal plant; Oroxylum indicum; rhizosphere

\section{Introduction}

Mycorrhiza is the symbiotic association established in between the fungal hyphae and the roots of vascular plants. This is the most popular symbiotic associations reported among the soil microorganisms and the plant roots. According to Singh et al., (2011) about $90 \%$ of the vascular plants are reported for the existence of mycorrhizal fungi. Ectomycorrhiza, ericoid mycorrhiza, arbutoid mycorrhiza, monotropoid mycorrhiza, orchid mycorrhiza, arbuscular mycorrhiza and ectendomycorrhiza etc. are the recently recognized mycorrhizal types (Bhattacharyya and Jha, 2015; Smith and Read, 2008). Arbuscular mycorrhizal fungi (AMF) are ubiquitous in plant taxa (Asmelash et al. 2016). This is the associations of phycomycetes septate fungus belonging to Glomeromycota that corresponds to five different genera such as Glomus, Gigaspora, Acaulospora, Scutellospora and Sclerocystis (Bhattacharyya and Jha, 2015). AMF consists of specialized structures called arbuscules and vesicles (Smith and Gianinazzi-Pearson, 1988). Arbuscules are dichotomously branched hyphal structures, the major site of nutrient exchange between the host and the mycorrhizal fungi. While, vesicles are globose to subglobose hyphal structures that usually serves as temporary storage organs. The vesicles are wellknown to provide drought resistance and assisting

\footnotetext{
*Corresponding Author:

Liza Bhattacharyya

Silviculture and Forest Management Division,

Rain Forest Research Institute,

Jorhat 785001, Assam, India.

E- mail: liza.handique@yahoo.in
}

the host plant to develop an effective and more efficient root system. AMF plays important role in maintaining the soil fertility and plant nutrition (Bhardwaj et al., 2014). They can make the event possible through enhancing the uptake and translocation of mineral nutrients like phosphorous, nitrogen, sulphur, potassium, calcium, iron, copper and zinc from soil to the host plants. AM fungi associated with the medicinal plants are also known to enhance the plant growth and improve the active metabolites (Chanda et. al, 2014).

India is an important mega biodiverse country (Bhattacharyya, 2012). North-East India being rich in medicinal plants and many other rare and endangered taxa has already sealed its position as an active centre of novel gene pools (Bhattacharyya et al., 2011; Chatterjee et al., 2006). Reports are there on the utilization of more than 1350 species of ethnomedicinal plants with diverse pharmacological research opportunities from this ecologically significant biodiverse zone (Chakraborty et al., 2012). Oroxylum indicum L. (Kurz.) belongs to the family Bignoniaceae (commonly known as bhatghila, trumpet flower, broken bone plant, bhut-vriksha etc.) is a small tree with purple to violet flowers as well as enormous seed pods that hang from the branches. 
The plant is recognized for various medicinal properties such as anti-inflammatory, anti-microbial, anti-oxidant, anti-arthritic, anti-diabetic etc. (Deka et al., 2013). A flavonoid, baicalein, extracted from the methanolic extract of Oroxylum indicum have been recorded for its efficacy to inhibit proliferation of cancer cell line in vitro (Roy et al., 2007). Bark juice of the plant is also effective drug in the treatment of jaundice (Sarma, 2012). Ayurvedic preparations such as Dasamula, Amartarista, Dantyadyarista, Brabma rasayana etc. also requires Oroxylum indicum as one of the active ingredients (Preety and Sharma, 2016).

However, scarce information is available on the AMF populations associated with this economically important plant. Keeping the point under consideration, the present investigation has been undertaken to determine the AMF colonization in the rhizosphere of Oroxylum indicum, an ethnomedicinally important plant of N.E. India. The present investigation is the first report accounting the comparative assessment of AMF populations in the rhizosphere of Oroxylum indicum collected from two geographically distinct study locations of N. E. India.

\section{Materials and Methods \\ Survey and sample collection}

Rhizospheric soil samples and roots of Oroxylum indicum were collected from two different sampling points of Jorhat district $\left(26^{\circ} 46^{\prime} 52^{\prime \prime} \mathrm{N} \& 94^{\circ} 12^{\prime} 30^{\prime \prime}\right.$ E), Assam and Naginimora (26 $46^{\circ} 44.7^{\prime \prime} \mathrm{N} \& 94^{\circ} 46^{\prime}$ 59.6" E), Mon district of Nagaland, N.E. India. The vegetation pattern of Oroxylum indicum is shown in Fig. 1. The sampling points were coded as JRT/BPS/OI-01 and JRT/BPS/OI-02 for two sampling points at Jorhat district, Assam and MON/NGM/OI-01 and MON/NGM/OI-02 for the two sampling points at Mon district, Nagaland respectively. The sampling points are shown in Fig. 2. The rhizospheric soil samples (approx. 500g) were collected randomly (three samples at each sampling point) from a depth of $1-15 \mathrm{~cm}$ (top soil). The collected soil was air-dried and used for mycorrhizal spore quantification purposes. The fine roots of the experimental plant were collected and preserved at $4^{\circ} \mathrm{C}$ to examine the root colonization.

\section{Determination of mycorrhizal colonization}

Arbuscular mycorrhizal colonization was determined by rapid clearing and staining method as suggested (Phillips and Hayman, 1970). For this, the roots were cut into small pieces $(1.0 \mathrm{~cm}$ each) and thoroughly washed in sterile distilled water (SDW) and stored in $10 \%(\mathrm{w} / \mathrm{v}) \mathrm{KOH}$ for overnight. This is followed by treatment with $1 \% \mathrm{HCl}$ and finally stained with trypane blue. The roots were destained with lactophenol and mounted in lactic acid and glycerol and observed under trinocular light microscope for the possible existence of mycelium, arbuscules and vesicles. Mycorrhizal root colonization was estimated using the following formula

\section{Mycorrhizal root colonization $=\frac{\text { Total no. of infected root segments }}{\text { Total no. of root segments examined }} \times 100$}

Quantification of AM spores and identification

The arbuscular mycorrhizal spores in the soil samples were determined by wet sieving and decanting technique (Gerdemann and Nicholson, 1963). The collected spores were mounted on polyvinyl lactoglycerol (PVLG) to observe their spore characteristics and identification purposes. The quantitative analysis of spores was measured with modified quantitative analysis technique (Gaur and Adholeya, 1994) using stereobinocular microscope. The AM spores were identified based on diverse morphological characteristics such as colour, size, shape, wall structure, surface, ornamentation of spores, nature and size of subtending hyphae, bulbous suspensor, the number and arrangement of spores in the sporocarp etc. Taxonomic monographs (Morton and Benny, 1990; Morton and Reddcker, 2001; Schenck and Perez, 1990, Trappe, 1982, Walker, 1983) were used for the AM spore identification.

\section{Species diversity indices}

Shannon-Wienner diversity index and Simpson's index of diversity were calculated using the following formulae:

Where,

$$
H_{S}=-\Sigma(p i)(\ln p i)
$$

$H_{S}=$ Symbol for the diversity in a sample of S species or kind

$S=$ The number of species in the sample

$p i=$ Measures the relative abundance of $i^{\text {th }}$ species or kinds $=\frac{n i}{N}$

$N=$ The total number of individuals of all kinds

$n \boldsymbol{i}=$ The number of individuals of $\mathrm{i}^{\text {th }}$ species $\ln =\log$ of base 2

Simpson's index of diversity $=1-\mathrm{D}$

Where, $\mathrm{D}=\Sigma\left(\frac{n}{N}\right)^{2}$

$n=$ The total number of organisms of a particular species

$N=$ The total number of organisms of all the species

\section{Results and Discussion}

Table 1 represents the quantitative estimation of AM spores and percentage root colonization of Oroxylum indicum per $50 \mathrm{gm}$ soil in different sampling locations. The present investigation indicated significant root colonization as well as spore counts at almost all the sampling points, although the percent root colonization and spore count varies with topographical variations. Geographical variations among the sampling locations played a significant role in affecting the AMF populations (Jansa et al., 2014). Arbuscular infection was highest (up to $100 \%$ ) in both the sampling points of Naginimora, Mon district, Nagaland, followed by JRT/BPS/OI-01 $(75 \pm 7.07 \%)$ and JRT/BPS/OI-02 (65 $\pm 7.07 \%)$ 
respectively. Root colonization with arbuscles is shown in Fig. 3. Vesicular infections (Fig. 4) were recorded maximum in $\mathrm{MON} / \mathrm{NGM} / \mathrm{OI}-01$ and MON/NGM/OI-02 (100 $\pm 0 \%$ at each sampling points). Vesicular infection was minimum (up to $30 \pm 0 \%$ ) at the sampling points in Jorhat district. However, all the sampling locations showed characteristically similar hyphal infections (up to $100 \pm 0 \%$ ). Spore count was calculated as maximum $(1239 \pm 13.4)$ in $\mathrm{MON} / \mathrm{NGM} / \mathrm{OI}-01$ and minimum

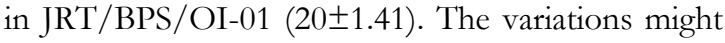
be attributed to the soil edaphic factors as well as altitudinal variation and vegetation types. Jorhat and Naginimora lies at $116 \mathrm{~m}$ and $312 \mathrm{~m}$ AMSL (Above Mean Sea Level) respectively and high altitudinal gradient might be one of the reasons for such variations in the distributional pattern of $\mathrm{AMF}$ populations. Studies pertaining to the AMF associations with Oroxylum indicum have earlier reported by Zhao et al., (2001), where they observed AMF root colonization with this economically important plant. Investigations pertaining to effect of altitudinal variations on species diversity and richness of AM fungi associated with 3 medicinal plants (Catharanthus roseus, Ocimum spp. and Asparagus racemosus) have been made by Gaur and Kaushik (2012), who observed some negative correlation of spore density and root colonization with altitude. There are variations in the relative occurrence of AMF populations at different study locations. Table 2 depicts the qualitative analysis of AMF in different sampling locations. It was observed that the AMF in the sampling point JRT/BPS/OI-01 belongs to 3 genera Acaulospora (A. foveata, A. lacunosa, A. laevis, Acaulospora sp.), Glomus and Scutellospora. Similarly, the sampling point JRT/BPS/OI-02 also indicates the existence of 3 genera such as Acaulospora, Glomus and Scutellospora. Acaulospora foveata, A. lacunosa, Acaulospora sp., Glomus mosseae, Glomus sp. and Scutellospora sp. are the species representatives under the observed categories. The AMF populations in the sampling point MON/NGM/OI-01 recorded the existence of 22 species belonging to 5 different genera such as Acaulospora ( $A$. foveata, A. lacunosa, $A$. bireticulata, $A$. mellea, A. laevis, A. rehmii, Acaulospora sp.), Glomus ( $G$. clavisporum, G. reticulatum, G. macrocarpon, G. mosseae, $G$. claroideum, G. pansihalos, G. albidum, G. geosporum, G. epigaeum, G. tunicatus, Glomus sp.), Gigaspora (G. gigantis, Gigaspora sp.), Entrophospora and Scutellospora. The sampling location MON/NGM/OI-02 also showed the existence of five different types of AMF genera such as Acaulospora, Glomus, Gigaspora, Entrophospora and Scutellospora. However, the species, Acaulospora bireticulata and Gigaspora sp. was absent in the sampling point. The photographs of some of the isolated AM spores have been shown in Fig. 5(A-D). Fig. 6 shows the percent occurrence of AM spores in the study locations. Glomus was the dominant AM species at all the sampling points followed by Acaulospora. The percent occurrence of Glomus is maximum in JRT/BPS/OI-02 (59.09\%), followed by JRT/BPS/OI-01 (55\%). Occurrence of Glomus was least in MON/NGM/OI-02(43.20\%). Occurrence of Acaulospora is more in JRT/BPS/OI-01 (40\%) and less in JRT/BPS/OI-02 (31.82\%). There were also distinct variations in the occurrences of other genera like Gigaspora, Entrophospora and Scutellospora throughout the study locations. The result of the present investigation indicates that the target plants collected from the sampling points of Nagaland are much more dependent on AM fungi for their survival than those from Jorhat. Wu et al., (2013) reported that the influence of vegetation type and forest composition as contributing factors for the existence of diverse fungal populations in a particular soil habitat. According to Imhof, (2010) monocots are best suited to develop myco-heterotrophy. The sampling points in Mon district, Naginimora were rich in monocots. Abundance in monocotyledonous vegetation in Mon district might influence the AM sporulation resulting in diverse AMF taxa as well as more AMF colonization in the sampling points.

Table 1: Percentage root colonization and spore count at different sampling points of N. E. India.

\begin{tabular}{llccccc}
\hline $\begin{array}{c}\text { Geographical } \\
\text { variations }\end{array}$ & Sampling points & $\begin{array}{c}\text { Root } \\
\text { colonization } \\
\mathbf{( \% )}\end{array}$ & $\begin{array}{c}\text { Hyphae } \\
\text { infection } \\
\mathbf{( \% )}\end{array}$ & $\begin{array}{c}\text { Arbuscular } \\
\text { infection (\%) }\end{array}$ & $\begin{array}{c}\text { Vesicular } \\
\text { infection } \\
\mathbf{( \% )}\end{array}$ & $\begin{array}{c}\text { Quantification of } \\
\text { AM spores }\end{array}$ \\
\hline Jorhat district, & JRT/BPS/OI-01 & $100 \pm 0$ & $100 \pm 0$ & $75 \pm 7.07$ & $30 \pm 0$ & $20 \pm 1.41$ \\
Assam & JRT/BPS/OI-02 & $100 \pm 0$ & $100 \pm 0$ & $65 \pm 7.07$ & $30 \pm 0$ & $22 \pm 1.41$ \\
Mon district, & MON/NGM/OI-01 & $100 \pm 0$ & $100 \pm 0$ & $100 \pm 0$ & $100 \pm 0$ & $1239 \pm 13.44$ \\
Ngaland & MON/NGM/OI-02 & $100 \pm 0$ & $100 \pm 0$ & $100 \pm 0$ & $100 \pm 0$ & $1220 \pm 13.44$ \\
\hline
\end{tabular}

Table 2: Relative occurrence of AMF populations at different sampling points of $\mathrm{N}$. E. India.

\begin{tabular}{|c|c|c|c|c|}
\hline AMF populations & JRT/BPS/OI-01 & JRT/BPS/OI-02 & MON/NGM/OI-01 & MON/NGM/OI-02 \\
\hline Acaulospora foveata & + & + & + & + \\
\hline A. lacunosa & + & + & + & + \\
\hline A. bireticulata & - & - & + & - \\
\hline A. mellea & - & - & + & + \\
\hline Acaulospora laevis & + & - & + & + \\
\hline A. rebmii & - & - & + & + \\
\hline Acaulospora sp. & + & + & + & + \\
\hline Glomus clavisporum & - & - & + & + \\
\hline G. reticulatum & - & - & + & + \\
\hline G. macrocarpon & - & - & + & + \\
\hline G. mosseae & - & + & + & + \\
\hline G. claroideum & - & - & + & + \\
\hline
\end{tabular}




\begin{tabular}{lllll}
\hline G. pansibalos & - & - & + & + \\
G. albidum & - & - & + & + \\
G. geosporum & - & - & + & + \\
G. epigaeum & - & - & + & + \\
G. tunicatus & - & - & + & + \\
Glomus sp. & + & - & + & + \\
Gigaspora gigantius & - & - & + & + \\
Gigaspora sp. & - & - & + & + \\
Entrophospora sp. & - & + & + & + \\
Scutellospora sp. & + & & & + \\
\hline
\end{tabular}

+; Present, -; absent.

Table 3: Shannon-Weiner and Simpson diversity indices for the sampling locations.

\begin{tabular}{lcc}
\hline \multirow{2}{*}{ Sampling locations } & \multicolumn{2}{c}{ Diversity indices } \\
\cline { 2 - 3 } & Shannon-Weiner & Simpson index \\
\hline JRT/BPS/OI-01 & 1.373 & 0.65 \\
JRT/BPS/OI-02 & 1.591 & 0.764 \\
MON/NGM/OI-01 & 2.935 & 0.941 \\
MON/NGM/OI-02 & 2.779 & 0.931 \\
\hline
\end{tabular}
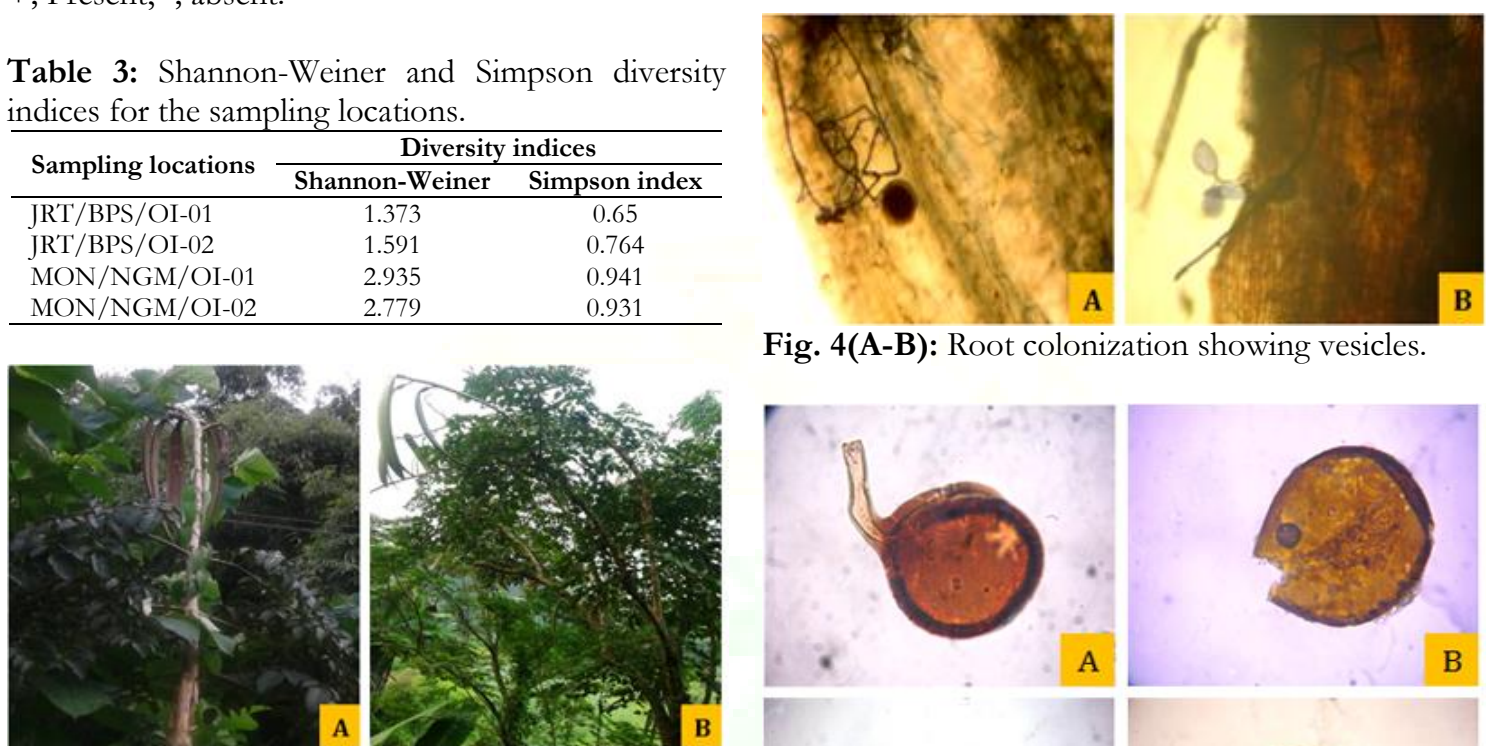

Fig. 4(A-B): Root colonization showing vesicles.

Fig. 1: A. General vegetation pattern of $O$. indicum in Jorhat district, Assam and B. Naginimora district of Nagaland, N. E. India.

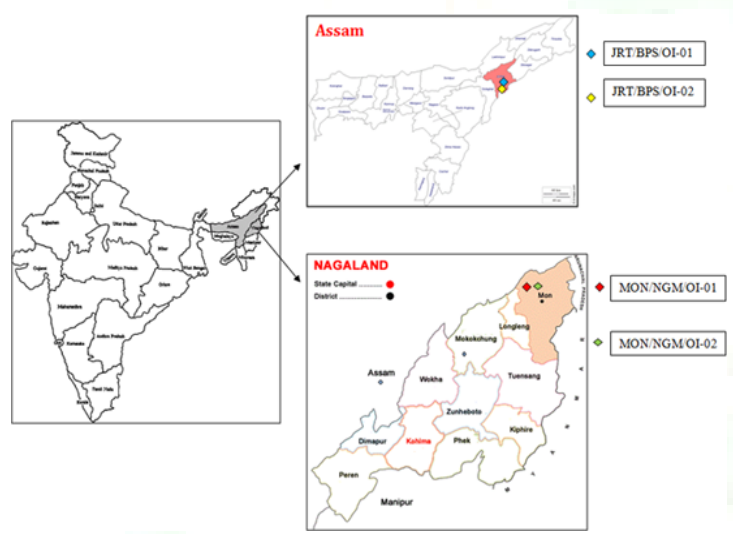

Fig. 2: Study area map showing the sampling locations.
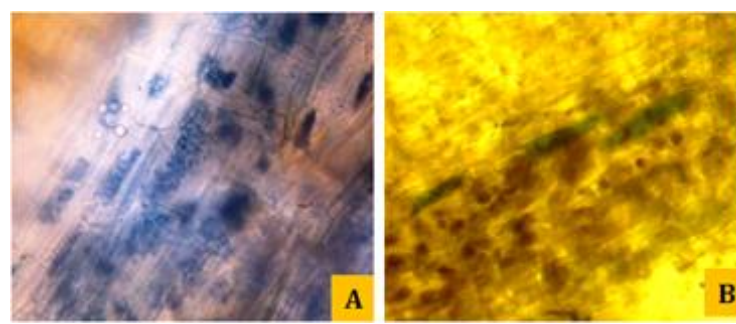

Fig. 3(A-B): Root colonization showing arbuscules.
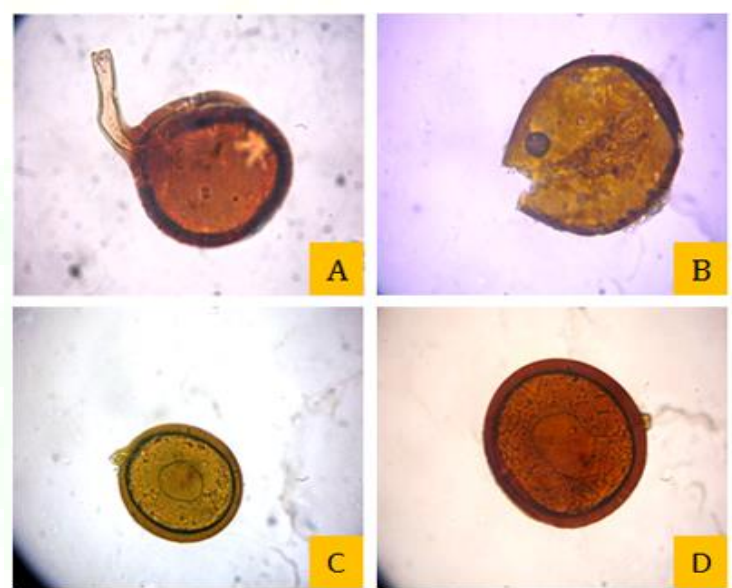

Fig. 5(A-D): Photographs of certain isolated spores. A. Glomus mosseae B. Acaulospora sp. C. Glomus albidum D. Glomus macrocarpon.

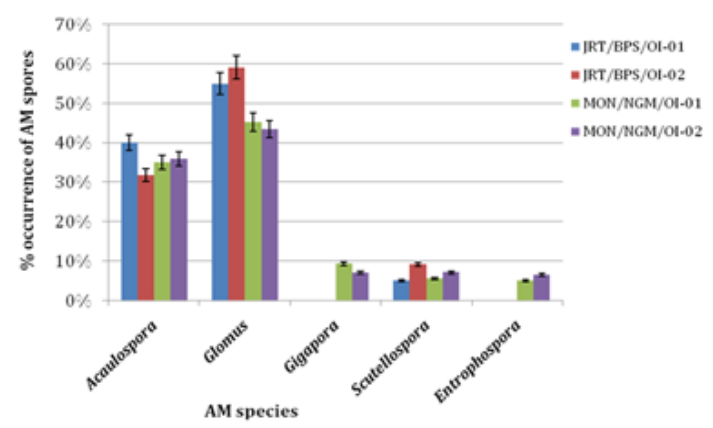

Fig. 6: Percentage occurrence of AM spores at different sampling points.

The Shannon Weiner and Simpson diversity indices also indicated distinct variations throughout the study locations (Table 3). Shannon Weiner and Simpson diversity indices were higher at sampling points MON/NGM/OI-01 and MON/NGM/OI02 , thus indicating high population diversity at those regions. More diverse spore populations and high species richness at these sampling locations might be due to the presence of more organic matter (Borah et 
al. 2015) that may assist the mycorrhizal colonization in the rhizosphere of the target plant species.

\section{Conclusion}

During the present investigation, it is evident that Oroxylum indicum is colonized by diverse AMF populations. There are variations in the AMF colonization density which varied significantly with topographical alterations. AMF showed maximum colonization and highest spore density at the sampling points of Naginimora (Mon district, Nagaland) while, the samples collected from Jorhat district showed comparatively low AM colonizations as well as spore count. Further investigations on the isolation and characterization of AM spores as well as works on diversity and relative abundance of AM fungi associated with Oroxylum indicum in relation to alterations in altitude, soil type and geographical variations are need to be explored to understand the behavior of unexplored AMF populations associated with this economically important plant.

\section{Acknowledgements}

The corresponding author is thankful to the Principal, Jagannath Barooah (J.B.) College, Jorhat and the faculty members of the Department of Botany, J.B. College, for providing the necessary support and valuable suggestions in the present investigation. The authors are also grateful to the Director, Rain Forest Research Institute (RFRI), Jorhat for providing the research facilities and guidance.

\section{References}

1. Asmelash F, Bekele T, Birhane E. The potential role of arbuscular mycorrhizal fungi in the restoration of degraded lands. Frontiers in Microbiology, 2016, 7, 1095.

2. Bhattacharyya PN, Baruah C, Jha DK, Sharma DK, Potential application of microbial resources in North East India: future prospects and challenges, NeBIO, 2011, 2, 12-18.

3. Bhattacharyya PN, Diversity of microorganisms in the surface and subsurface soil of the Jia Bharali river catchment area of Brahmaputra plains. $\mathrm{PhD}$ Thesis, Gauhati University, Guwahati, Assam, India, 2012.

4. Bhattacharyya PN. Jha DK, Mycorrhizal symbiosis in the formation of antioxidant compounds. In: Plants as a source of natural antioxidants. Dubey NK, (eds.) CAB International, Oxfordshire, UK, 2015, pp., 252281.

5. Bhardwaj D, Ansari W, Sahoo RK, Tuteja N, Biofertilizers function as key player in sustainable agriculture by improving soil fertility, plant tolerance and crop productivity. Microbial Cell Factories, 2014, $13,66$.

6. Borah G, Bhattacharyya LH, Parkash V, Bhattacharyya PN, Rhizospheric fungal diversity associated with Meyna spinosa Roxb.: a threatened and ethno-medicinally important plant of North-East India. International Journal of Current Microbiology and Applied Sciences, 2015, 4, 295-303.

7. Chakraborty R, Biplab De, Devanna N, Sen S, NorthEast India an ethnic sstorehouse of unexplored medicinal plants. Journal of Natural Product and Plant Resources, 2012, 2, 143-152.

8. Chanda D, Sharma GD, Jha DK, Hijri M, The potential use of arbuscular mycorrhiza in the cultivation of medicinal plants in Barak valley, Assam: a review. Current World Environment, 2014, 9, 544551.

9. Chatterjee S, Saikia A, Dutta P, Ghosh D, Pangging G, Goswami AK, Biodiversity significance of North East India. Forests Conservation Programme, WWF-India, New Delhi, 2006.

10. Deka DC, Kumar V, Prasad C, Kumar K, Gogoi BJ, Singh L, Srivastava RB, Oroxylum indicum-a medicinal plant of North East India: an overview of its nutritional, remedial, and prophylactic properties. Journal of Applied Pharmaceutical Science, 2013, 3, S104-S112.

11. Gaur A, Adholeya A, Estimation of VAMF spores in soil: a modified method. Mycorrhizae News 1994, 6, 10-11.

12. Gaur S, Kaushik P, Effect of seasonal variation on mycorrhizal fungi associated with medicinal plants in central Himalayan region of India. American Journal of Plant Sciences, 2012, 3, 618-626.

13. Gerdemann JW, Nicolson TH, Spores of mycorrhizal endogone species extracted from soil by wet sieving and decanting. Transactions of the British Mycological Society 1963, 46, 235-244.

14. Imhof $S$, Are monocots particularly suited to develop mycoheterotrophy. In: Seberg O, Peterson G, Barfod AS, (eds)., Diversity, phylogeny, and evolution in the Monocotyledons. Aarhus University Press, Aarhus, Denmark, 2010, pp. 11-23.

15. Jansa J, Erb A, Oberholzer HR, Smilauer P, Egli S, Soil and geography are more important determinants of indigenous arbuscular mycorrhizal communities than management practices in Swiss agricultural soils. Molecular Ecology, 2014, 23, 2118-2135.

16. Morton JB, Benny GL, Revised classification of arbuscular mycorrhizal fungi (Zygomycetes): a new order, Glomales, two new suborders, Glomineae and Gigasporineae, and two families, Acaulosporaceae and Gigasporaceae, with an emendation of Glomaceae. Mycotaxon, 1990, 37, 471-491.

17. Morton JB, Redecker D, Two new families of Glomales, Archaeosporaceae and Paraglomaceae, with two new genera, Archaeospora and Paraglomus, based on concordant molecular and morphological characters. Mycologia, 2001, 93: 181-195.

18. Phillips JM, Hayman DS, Improved procedures for clearing and staining parasitic and vesicular- 
arbuscular mycorrhizal fungi for rapid assessment of infection. Transactions of the British Mycological Society, 1970, 55, 158-161.

19. Preety A, Sharma S, (A review on Oroxylum indicum (L.) Vent: an important medicinal tree. International Journal of Research in Biological Sciences 2016, 6, 7 12.

20. Roy MK, Nakahara K, Na TV, Trakoontivakorn G, Takenaka M, Isobe S, Tsushida T, Baicalein, a flavonoid extracted from a methanolic extract of Oroxylum indicum inhibits proliferation of a cancer cell line in vitro via induction of apoptosis. Pharmazie. 2007, 62, 149-53.

21. Schenck, NC, Perez Y, Manual for the identification of VA Mycorrhizal fungi. ( $3^{\text {rd }}$ edn). Gainesville, Florida, Synergistic Publications, 1990.

22. Sharma J, Gairola S, Gaur RD, Painuli RM, The treatment of jaundice with medicinal plants in indigenous communities of the Sub-Himalayan region of Uttarakhand, India. Journal of Ethnopharmacology 2012, 143, 262-91.

23. Singh, LP, Gill SS, Tuteja N, Unraveling the role of fungal symbionts in plant abiotic stress tolerance. Plant Signaling \& Behavior, 2011, 6, 175-191.

24. Smith SE, Gianinazzi-Pearson V, Physiological interactions between symbionts in vesiculararbuscular mycorrhizal plants. Annual Review of Plant Physiology and Plant Molecular Biology, 1988, $39,221-244$.
25. Smith SE, Read DJ, Mycorrhizal Symbiosis, Academic Press, New York, 2008.

26. Trappe JM, Synoptic keys to the genera and species of Zygomycetous mycorrhizal fungi. Phytopathology, 1982, 72, 1102-1108.

27. Walker C, Taxonomic concepts in the Endogonaceae spore wall characteristics in species description. Mycotaxon, 1983, 18, 443-445

28. Wu YT, Wubet $\mathrm{T}$, Trogisch S, Both $\mathrm{S}$, Scholten $\mathrm{T}$, Bruelheide H, Buscot F, Forest age and plant species composition determine the soil fungal community composition in a Chinese subtropical forest PLoS One, 2013, 8, e66829.

29. Zhao ZW, Qin XZ, Li XW, Cheng LZ, Sha T, Wang $\mathrm{GH}$, Arbuscular mycorrhizal status of plants and the spore density of arbuscular mycorrhizal fungi in the tropical rain forest of Xishuangbanna, southwest China. Mycorrhiza, 2001, 11, 159-162.

\section{Cite this article as:}

Aatreyee Nath, Liza Handique Bhattacharyya, Pranaba Nanda Bhattacharyya, Vipin Parkash, Bijay Sharma. Comparative assessment of arbuscular mycoorhizal fungi (AMF) associated with Oroxylum indicum L. (Kurz.)- an ethno-medicinal plant of N. E. India. Annals of Plant Sciences 5.9 (2016): 1428-1431. DOI: http://dx.doi.org/10.21746/aps.2016.10.004

Source of support: Rain Forest Research Institute (RFRI), Jorhat.

Conflict of interest: None Declared 